\title{
Assessing the Impact of an Operating Tailings Storage Facility on Catchment Surface and Groundwater Quality in the Ellembele District of the Western Region of Ghana
}

\author{
Elvis Akwasi Acheampong ${ }^{1} \&$ Daniel Nukpezah ${ }^{1}$ \\ ${ }^{1}$ Institute for Environment and Sanitation Studies, University of Ghana, Ghana \\ Correspondence: Elvis Akwasi Acheampong, Institute for Environment and Sanitation Studies, University of \\ Ghana, Ghana. E-mail: elvisacheampong91@yahoo.com
}

Received: July 20, 2016 Accepted: August 17, 2016 Online Published: September 29, 2016

doi:10.5539/ep.v5n2p26 URL: http://dx.doi.org/10.5539/ep.v5n2p26

\begin{abstract}
The study assessed the impact of an operating Tailings Storage Facility (TSF) of Adamus Resources Limited (Nzema Gold Mine) in the Ellembele District of the Western of Ghana on catchment surface and groundwater quality. Water samples were collected between June and December 2014 from seventeen (17) sampling sites including the TSF decant water (TSF-DW), three (3) streams, a water storage dam, a pond and eleven (11) groundwater monitoring boreholes within $500 \mathrm{~m}$ radius of the mine's Tailings Storage Facility. Samples were analyzed for $\mathrm{pH}$, true colour, electrical conductivity (EC), total dissolved solids (TDS), total suspended solids (TSS), biological oxygen demand (BOD), dissolved metals (arsenic, cadmium, copper, mercury) and cyanide (weak acid dissociable cyanide (WAD), free cyanide and total cyanide) using standard procedures. The TSF-DW reported elevated arsenic, free cyanide and TSS concentrations above GHEPA guideline for effluent discharge. Elevated TSS and arsenic concentrations above GHEPA limits were reported in PWSD which is a pond uphill of the TSF and a receptor to effluents from illegal mining sites on the mine's concession. All other parameters recorded in surface and groundwater bodies studied were within WHO guideline limit for potable water. Results of the study suggest that the quality of surface and groundwater around the TSF has not been adversely affected even though the TSF is contaminated. Study findings suggest that well-engineered tailings dam ofARLwith its effective liner and management systems may have provided a safe structure and prevented contamination of water resources within its catchment.
\end{abstract}

\section{Introduction}

Mining plays a key role in the socio-economic development of many countries and Ghana is a good example. Hinton, Veiga \& Beinhoff (2003) outlined positive aspects of mining including creation of employment, contribution to government revenue, foreign currency earnings and increase of Gross Domestic Product (GDP). Mining operations generally produce many types of waste including tailings and waste rocks, many of which are dumped or contained in facilities near extraction or processing sites. Wastes generated from such mining operations are of grave concern to stakeholders such as mining companies, governments and communities owing to their potential detrimental impacts on water resources and the environment in general. Many mining operations also utilize large volumes of water for mineral processing, controlling dust, and meeting the diverse needs of workers on site (Acheampong, Adiyiah, \& Ansa, 2013).

Mine tailings, which are solid-liquid slurry materials made up of fine-grained waste particles remaining after ore treatment (e.g., milling, flotation, separation, leaching), are often stored in a Tailings Storage Facility (TSF) and managed to optimize the amount of tailings stored as well as reduce potential adverse environmental impacts. According to Liu et al. (2008), the components of mine tailings depend to a large extent on the chemicals and the method used in the mineral extraction, as well as the geology of the mined ore been processed. Tailings from mineral processing, in particular, serve as a main source of contamination of catchment surface and groundwater resources (Roussel, Néel, \& Bril, 2000). The liquid component of tailings is made up of water and chemicals used in ore processing. Contents of TSFs could therefore be highly contaminated and are therefore not discharged directly into the environment in conformity with international best practice for mining industries. It is therefore imperative to properly manage tailings as they constitute a major source of release of many trace elements and other contaminants into the environment (Armah et al., 2010). 
For gold bearing ore, a greater part of ore processed ends up as tailings or process waste that must be discarded (Paull, Banks, Ballard, \& Gillieson, 2006). After mineral concentrate has been separated from ore, the unrecoverable and uneconomic metals, minerals, chemicals, organics and process water are sent via a pipeline as slurry to a secured storage facility or dam at the mine site (Tailings Storage Facility or TSF or Tailings Management Facility or TMF) (Vick, 1990). Tailings usually include metal precipitates resulting from neutralization sludges or residues from pressure leaching processes. Such materials may exhibit long-term chemical stability concerns and need to be disposed in secure, lined facilities. A TSF or TMF is a large area usually located in a natural hollow or valley.

Tailings storage facilities are important and indispensable components in the mining and processing of minerals. Depending on methods used in construction, geology of mine sites, climate, nature of ore mined and/or treated, and overall management, tailings storage facilities may exact variable impacts on the immediate surrounding environment. According to Vick (1990), seepage of some process water from Tailings Storage Facilities may be inevitable irrespective of the facility's engineering design. Azcue, Mudroch, Rosa, $\&$ Hall (1994) also suggest that problems arise where excess seepage of process waste from the TSF impacts on the environment.

In Ghana, the mining industry contributes $40 \%$ of gross foreign exchange earnings and directly employs about 18,000 people, most of whom are Ghanaians (Hilson, 2005). The sector also contributes to development through implementation of Corporate Social Responsibility (CSR) programmes for host communities and the general public at large.

Because of the important role mining plays in the economy of Ghana, the government and regulatory agencies such as the Environmental Protection Agency (EPA) and Minerals Commission closely monitor the activities of mining companies to ensure the country maximizes the benefits and minimize risks or negative impacts including pollution of the environment that may result from mining operations.

Many large-scale mining companies in Ghana, such as Adamus Resources Limited located in the Ellembelle district of Ghana, often operate in areas also inhabited by local communities within the catchment areas of the mine. Communities such as Tarkwa, Nsuta, Teberebie, Teleku-Bokazo and New Abirem are, for example, also located in the proximities of mining operations.

Groundwater contamination is of grave concern where it feeds surface streams or lakes, and where the groundwater is a source of drinking water and other domestic uses by people living close to a mine (Smedley, Edmunds, \& Pelig-Ba, 1996).

Adamus Resources Limited which is a subsidiary of Endeavour Mining of Canada, operates a surface gold mine in the Ellembele District in the Western Region of Ghana. The company has a Tailings Storage Facility (TSF) which receives effluents from processing of sulphide (mainly arsenopyrite-rich) ore. The mine and its TSF are located in an area that is also inhabited by local communities that depend on surface and groundwater resources in the proximity of the mining and ore processing activities.

Several studies have reported high metal concentrations in water, soil, food and biological tissues around settlements close to tailings dams in Obuasi, Prestea and Tarkwa townships of Ghana (Smedley et al. (1996); Ahmad \& Carboo (2000); Akabzaa, Banoeng-Yakubu, \& Seyire (2005). However, studies on the impact of TSF on catchment water bodies are unavailable in the Ellembele District of Ghana, as mining operations have only recently started in the area. In addition, communities close to Adamus Resources Limited (ARL) which is the first large scale mining firm to operate in the area depend largely on surface and groundwater for drinking, subsistence agriculture and other domestic uses. This study therefore assessed the quality of surface and groundwater resources in the proximity of ARL's tailings facility to determine whether, after four years of active mining and ore processing, there are perceptible impacts on the surface and underground water resources.

\section{Study Area}

The Nzema Gold Mine is located in the Ellembele district of the Western Region of Ghana and is approximately $280 \mathrm{~km}$ west of the capital, Accra, and less than $20 \mathrm{~km}$ from the coast at Essiama. The mine is accessed from Accra via the main coast highway to Takoradi and from there by sealed road $(77.6 \mathrm{~km})$ to the village of Teleku- Bokazo and then by $10 \mathrm{~km}$ of untarred road. The current project setting consists of the following concessions; Salman, Akanko and Ebi-Teleku-Bokazo, which covers a total area of $92.3 \mathrm{sq} . \mathrm{km}(9,230 \mathrm{ha})$. The mine footprint is estimated to disturb an area totaling approximately $0.4 \%$ of the total land take. The project falls within the Nzema East and Jomoro Traditional Areas and is situated in the Wet Evergreen Forest Zone with an average annual rainfall of about $2000 \mathrm{~mm}$ (Knight Piesold, 2007). The project lays within three major drainage systems namely the 
Ankobra River to the east, the Amansuri lagoon to the west and the Biare catchment that flows to the south into the Atlantic Ocean.

The site is largely transformed as a result of extensive human induced degradation. The main land uses include subsistence and cash crop farming, logging and illegal artisanal mining. There are six distinct communities within the Project area, namely Teleku-Bokazo, Anwia, New Aluku, Salman, Akanko and Duale (Ichino \& Nathan, 2013). Additionally, a number of smaller satellite communities also exist within the project catchment area. The location of the study area is shown in Figure 1.

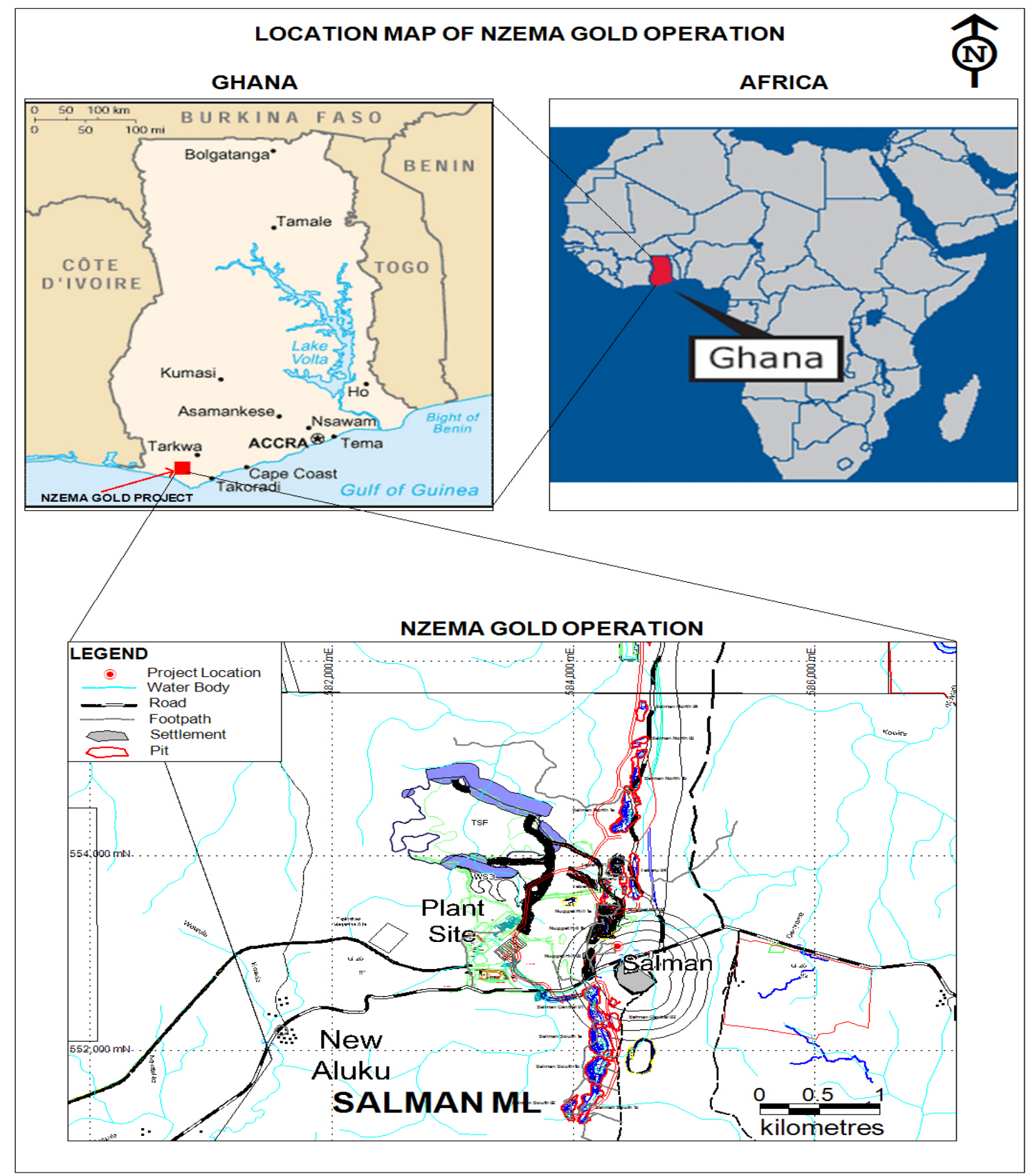

Figure 1. Map of study area showing key areas of mining operations

Source: Knight Piesold (2007). 


\subsection{Local Geology and Soils}

Basement exposure is generally poor within the Project area and is largely restricted to road cuttings, a few stream beds, prospecting pits and trenches, and drill pads (Dzibodi-Adjimah, 1993). Laterite and mottled clay zones are locally developed on ridges, and saprolite typically extends to $10-30$ metres beneath surface and locally as much as $80 \mathrm{~m}$. The eastern part of the Project is largely underlain by Birimian volcanic and volcaniclastic rocks assigned to the Ashanti Belt, the western part mainly by Birimian metasedimentary rocks of basin and basin margin affinity in the southeastern corner of the Kumasi Basin (Dzibodi-Adjimah, 1993).

The Birimian volcanics are thought to be faulted against the Tarkwaian Group immediately northeast of the current tenure, and a small area of quartz-rich fluvial rocks immediately east of Axim may also belong to the Tarkwaian. A large biotite ganite body is exposed in the western part of the Project area and probably belongs to the Cape Coast suite (Leube, Hirdes, Mauer, \& Kesse, 1990). Two large, magnetically zoned Dixcove-type granitoid batholiths intrude the volcanics at the eastern edge of the Project, and curved magnetic ridges adjacent to these intrusives could represent contact aureoles (Dzigbodi-Adjimah, 1993). Several narrow granitoid dykes and fault slivers up to 13 kilometres long and 700 metres thick of uncertain affinity are scattered through the Project area, and some near-circular geophysical features (electromagnetic resistors with weakly magnetic edges) between 1.5 and $2.0 \mathrm{~km}$ diameter, northeast of Anwia may represent subsurface plutons (Knight Piesold, 2007). Two north-striking doleritic dykes are known from geophysics and drilling in the Nkroful-Anwia area.

There is no formal subdivision of the Birimian Supergroup in the Southern Ashanti area but several lithologically and geophysically distinct units can be identified and three litho-structure domains are recognised: Avrebo, Salman and Anwia. The soils of the Project area have developed over the sediments of the Lower Birimian rocks and belong to the Boi Soil Association (Knight Piesold, 2007). The soils are deeply weathered and intensively leached of bases rendering them acidic and low in fertility. The series members of the Association within the Project site according to a study by Knight Piesold (2007) are the Omappe, Boi, Bremang and Oda series. The commonest features of the soils of the site are their great depths, strong brown to yellowish colour, acidic reaction, moderate fertility levels, high nutrient levels, clayey texture, sticky and plastic consistence and high contents of hard fresh quartz gravels and stones resulting from the weathering of quartz veins embedded in the subsoil (Dzigbodi-Adjimah, 1993).

\subsection{Design and Construction Background of the Nzema Tailings Storage Facility}

The TSF was constructed in the year 2010 and is a cross-valley type impoundment located immediately due north of the plant site. It was designed by Knight Piesold (KP) Consulting to store tailings at a maximum capacity of 18 million tonnes. The storage is created by the construction of a main confining embankment across the valley some $2 \mathrm{~km}$ downstream of the treatment plant site (Knight Piesold, 2007). Tailings are deposited into the facility by multi-point spigot discharge from the main embankment and small east-west trending saddle dam. This deposition pattern will result in a tailings surface that slopes downwards to the south where the supernatant pond is formed remote from confining embankments (Vick, 1990). A series of decant towers are constructed in the southern part of the facility from which supernatant water are reclaimed and returned to the plant site.

An under-drainage system is constructed within the basin area to minimize seepage to the local groundwater (Azcue et al., 1994). The system comprises a series of drainage pipes, surrounded by sand drainage material laid on the basin floor. Water intercepted and collected by the system is drained to a sump located immediately upstream of the main embankment. A groundwater drainage system is also in place and this comprises a $160 \mathrm{~mm}$ diameter drain-coil pipe in a $1 \mathrm{~m}^{2}$ cross-section of clean crushed granite aggregate which is surrounded by geo-textile and backfilled with compacted clay prior to constructing the impervious compacted clay soil liner.

The technical justification for the ground water drainage system is based on the principles of groundwater hydrology, namely that the water table in the hills surrounding the TSF is draining by gravity through the fractured and weathered rocks to come to surface in the stream bottoms and then drain by gravity on surface (Rico, Benito, Salgueiro, Díez-Herrero, \& Pereira, 2008). The groundwater is conveyed under the soil liner by a drainage system to avoid uplift and penetration of the liner. The ground water drain is expected to yield less and less water over time as the recharge area is progressively reduced by the increasing area of the liner in the catchment and as the stored water in the hills is slowly drawn down over time (Davies, 2002). Water intercepted and collected by the ground water drain system is drained to a sump located immediately upstream of the main northern embankment.

Emergency spillways are constructed at each stage of facility development in the vicinity of a north-south trending saddle dam. A final spillway has been located in the small saddle, some $400 \mathrm{~m}$ south west of the plant site. The decant system for the facility comprises series of decant towers. The towers are located in the southern part of the facility. The two towers were constructed from pre-fabricated slotted concrete pipe and surrounded by coarse free 
draining rock-fill (Knight Piesold, 2007). A submersible pump is installed to pump water back to the plant via a High Density Poly-Ethylene (HDPE) reclaim line along the decant access road. The pump and return water line systems is capable of removing water from the pond at a rate equivalent to maximum plant demand.

The tailings delivery pipeline comprises a solid HDPE pipeline some 4,000 $\mathrm{m}$ long, located on the downstream side of the TSF access road. The alignment of the pipeline is such that any leakages from the line, due to a rupture or pipe break, will flow directly into the TSF and thus be contained. The TSF pipeline containment bund is fully lined with felt pad membrane. The future embankment raise is a downstream method.

\subsection{Materials and Methods}

\subsection{Study Design and Statistical Methods}

Water samples were collected between June and December 2014 from seventeen (17) sampling sites including the TSF decant water (TSF-DW), three (3) streams, a water storage dam, a pond and eleven (11) groundwater monitoring boreholes within $500 \mathrm{~m}$ radius of the mines Tailings Storage Facility. Water samples were collected on monthly basis consecutively from first week of June 2014 to the first week of December 2014. The sampling matrix was designed to capture both dry and wet seasons to ascertain the quality of water in the two key seasons experienced over the project area. The data obtained were subjected to descriptive statistical analysis $(95 \%$ confidence limit) and a correlation matrix was generated for parameters analyzed within the different media. Analysis of variance (ANOVA) was used to determine the variation amongst the various parameters sampled from the various sampling sites. All measurements were conducted at 5\% level of significance. Microsoft Excel 2010 and EQwin data management software were used in statistical analysis conducted in the study

\subsection{Locations of Groundwater Monitoring Borehole and Surface Water Sampling Sites}

Ground and surface water sampling locations were carefully selected to reflect the potential impacts of ARL's TSF on water resources within its catchment. Closeness of these sampling sites to the TSF makes them susceptible to pollutants through leachates and seepage from the facility.

Four (4) groups of two monitoring boreholes and three single deep boreholes have been strategically installed by the mine at the northern and eastern embankment to monitor possible seepage of contaminants from the TSF. Each monitoring borehole pair consists of one shallow borehole, extending through approximately $5-10 \mathrm{~m}$ of the near surface horizon and one deep borehole terminating at approximately $25 \mathrm{~m}$. The monitoring boreholes comprise $100 \mathrm{~mm}$ PVC pipe, with a $3 \mathrm{~m}$ slotted tip wrapped in geotextile. The boreholes are all capped with plastic material and locked to avert possible contamination of its content from external sources. In all, there are eleven (11) groundwater monitoring boreholes located at various points down gradient of the operating TSF of Nzema Gold Mine, which were sampled.

The shallow boreholes are designed to detect seepage flowing within the surface sediment whilst deep boreholes monitor the chemical composition of groundwater. Locations of the monitoring boreholes were informed by initial hydrological studies conducted prior to operation of the TSF by an independent engineering firm (Knight Piesod) and recommendations from the Environmental Protection Agency (EPA) of Ghana. The water storage Dam (WSD) shares boundary with the southern embankment of the Tailings Storage Facility. Pond besides Water Storage Dam (PWSD) is a pond $80 \mathrm{~m}$ uphill of the TSF at the south and $8 \mathrm{~m}$ away from the WSD. It used to be a stream that traverses the existing location of the TSF and the WSD before its construction and was later dammed by the mine to make way for the construction of the TSF and the WSD. It is stagnant and does not have any vertical flow. TSF North-West Stream (TSF-NWS) is located just at the toe of the TSF northwestern embankment about $10 \mathrm{~m}$ away from the facility. It recharges from a cocoa farm located on a hill at the west of TSF and drains eastwards. The stream channel is about $4 \mathrm{~m}$ wide and $0.5 \mathrm{~m}$ deep and flows in a dendritic pattern.

Angajale Stream (ANG) is located further northeast of the TSF and flows to join other streams which finally end up in the Ankobra River. It is monitored by the mine for surveillance purposes on monthly basis. The Angajale stream flows downstream of the TSF in north-eastern direction. The stream passes through the Angajale and Akango communities. It serves as the main source of water for farming and domestic use for the community folks.

Sampling point coded BAN-T is a perennial stream that flows in an easterly direction down gradient of the TSF North Embankment. It flows through Akango to join the Ankobra River. All surface and groundwater bodies studied were within $500 \mathrm{~m}$ radius of the TSF.

\subsection{Sample Collection and Analysis}

Prior to collection of water samples, the Horiba Multi-parameter (U-52) probe which was used for in-situ surface and groundwater quality analysis was calibrated with $500 \mathrm{ml}$ of HORIBA 100-4 pH standard solutions, 
as per the equipment's operating manual. Standard latex gloves were always worn and disposed of after sampling at each sampling site to avoid cross contamination. Proper purging before collection of samples is key to successful ground water sampling. This ensures that water sampled is of good quality and reflects natural conditions (Singh, Malik, Mohan, \& Sinha, 2004). In that regard, purging was done with the aid of portable generator set and submersible pump. Boreholes were purged for 5-10 minutes. In some instances, bailers were used when the generator set was faulty. Surface water samples were taken from below the surface $(75 \mathrm{~mm}$ minimum) of the surface water in flowing streams. Care was taken not to include any surface film in the water collected. Containers were slowly and gently filled to avoid contamination of sampled water and disturbance of the water during sampling. Samples bottles were made to face the flow direction of water bodies. Air bubbles were eliminated and the bottles capped tightly to prevent contamination and water spilling. In order to avoid errors and mix-ups of samples, sample bottles were labeled with permanent, legible markings with information on the following: Sample location or code; date and time; Parameters for analysis and Preservatives, if any (Parizek, \& Lane, 1970). Preservation methods are limited to: $\mathrm{pH}$ control, chemical addition, and refrigeration. The following parameters were preserved as follows: Metals: - Conc. $\mathrm{HNO}_{3}$ to $\mathrm{pH}<2$, after filtering with 0.45 -micron filter; Cyanide: $-\mathrm{NaOH}$ to $\mathrm{pH}>12$ (filter if turbid or TSS present).

Samples were packed upright in a cooler with ice packs to maintain the temperature of the samples just above freezing. A sample submission form ("chain of custody form") was filled out with all of the above information plus comments pertinent to the sample and transported to the laboratory for analysis.

\subsection{In-situ Measurements}

TDS, $\mathrm{pH}, \mathrm{BOD}$ and electrical conductivity were measured in-situ using Horiba multi parameter probe (Model No. Horiba $500, \mathrm{~S} / \mathrm{N})$. The probe was rinsed with distilled water after every measurement to avoid cross contamination. The most stable reading displayed by the probe was taken to be the actual reading. All samples collected were sent to SGS Mas laboratory at Tema for analysis. Analyses of water samples were carried out in line with strict laboratory standards and internationally accepted protocols.

\subsection{Analysis for Cyanide (CN)}

The titrimetric method was used for the analysis of $\mathrm{CN}$ species. A blank solution was titrated against standardized $0.1 \mathrm{M} \mathrm{AgNO} 3$ solution using p-dimethylamino benzalrhodanine indicator solution, until the colour of the indicator changed from cannary yellow to salmon blue. The blank titre was recorded and subsequently used. 100 $\mathrm{ml}$ of the sample was titrated against $0.1 \mathrm{M} \mathrm{AgNO}_{3}$ using $5 \mathrm{ml}$ of p- dimethylaminobenzalrhodanine as an indicator to the end point. Concentrations of total cyanide in the water samples were determined by distillation of the sample to which $10 \mathrm{ml}$ of conc. $\mathrm{HCl}$ and $10 \mathrm{ml}$ of $12 \% \mathrm{w} / \mathrm{v}$ hydroxylamine hydrogen chloride solution had been added to generate hydrogen cyanide gas $(\mathrm{HCN})$, which was absorbed into $2 \mathrm{M} \mathrm{NaOH}$ solutions. The resulting sodium hydroxide solution was further diluted to $250 \mathrm{ml}$ out of which $100 \mathrm{ml}$ was titrated against standardized 0.1 $\mathrm{M} \mathrm{AgNO}_{3}$ solution using $5 \mathrm{ml}$ of p-dimethylaminobenzalrhodanine indicator to the salmon blue end point (Kuhn \&Young, 2005). Concentrations of free and total cyanide in the samples were calculated as follows:

$\mathrm{CN}^{-} \mathrm{mg} / \mathrm{l}=(\mathrm{A}-\mathrm{B}) / 100 \mathrm{ml} *(250 / 1000) \mathrm{ml}$

where $\mathrm{A}=$ sample titre volume of $\mathrm{AgNO}_{3}$ and $\mathrm{B}=$ blank titre volume of $\mathrm{AgNO}_{3}$

\subsection{Total Suspended Solids Analysis (TSS)}

The photometric (non-filterable residue) method was used. $500 \mathrm{ml}$ of sample was blended at high speed for two minutes. This was poured into a $600 \mathrm{ml}$ beaker, stirred and $25 \mathrm{ml}$ immediately poured into a sample cell. The stored programme number for suspended solids, 630 , was entered. The wavelength was set to $810 \mathrm{~nm}$. A sample cell was filled with $25 \mathrm{ml}$ de- mineralized water (blank). This was placed in the cell holder and standardized. Next the sample was placed into the cell holder and the reading taken in $\mathrm{mg} / \mathrm{l}$ suspended solids.

\subsection{Dissolved Metals}

Metals in the water samples collected were determined using atomic absorption spectro-photometer (AAS), AAS 220 model. The samples for AAS were first digested with nitric acid before analysis. In the laboratory, the acidified samples were filtered using Whatman's filter paper. The $0.45 \mu \mathrm{m}$ membrane filter paper was used because the analyte of interest in this work is the total dissolved metals. The filtered samples and the unfiltered samples were stored in the refrigerator at $4{ }^{0} \mathrm{C}$ for further analysis (Serfor-Armah, Nyarko, Dampare, \& Adomako, 2006).

\section{Results and Discussion}

\subsection{Quality of the Tailings Decant Water}

The water quality parameters of Tailings Decant Water (TSF-DW) were mostly within Ghana EPA guideline 
limits for effluent discharge.

The $\mathrm{pH}$ of TSF-DW ranged from 7.4 to 8.9. Mean $\mathrm{pH}$ of 8.2 was within the GHEPA effluent guideline limit of 6-9. Electrical conductivity ranged from 1340 to $1630 \mu \mathrm{S} / \mathrm{cm}$ with a mean value of $1507.1 \mu \mathrm{S} / \mathrm{cm}$ which was slightly above the GHEPA guideline limit of $1500 \mu \mathrm{S} / \mathrm{cm}$ for effluent discharge.

Total Dissolved Solid (TDS) varied from 861 to $1040 \mathrm{mg} / 1$. The mean TDS of $964.5 \mathrm{mg} / \mathrm{l}$ reported in this study was well within the GHEPA guideline limit for effluent discharge.

Biochemical Oxygen Demand (BOD) recorded in TSF-DW was below the laboratory detection limit in the entire study. Values of true colour ranged between $<3$ and $40 \mathrm{TCU}$ with a mean value of $9.40 \mathrm{TCU}$ which was far below the GHEPA guideline limit for effluent discharge.

Total Suspended Solids values ranged between $19 \mathrm{mg} / \mathrm{l}$ and $105 \mathrm{mg} / \mathrm{l}$ with mean of $55.29 \mathrm{mg} / \mathrm{l}$ which was above the GHEPA guideline limit of $50 \mathrm{mg} / \mathrm{l}$.

Total cyanide (CN-t) concentration recorded in TSF-DW ranged between $<5$ and $1.55 \mathrm{mg} / \mathrm{l}$. Mean $\mathrm{CN}-\mathrm{t}$ concentration of $0.586 \mathrm{mg} / \mathrm{l}$ was below the recommended GHEPA threshold of $1 \mathrm{mg} / \mathrm{l}$. However, Free Cyanide $(\mathrm{CN}-\mathrm{f})$ concentration in the TSF-DW varied between $<0.005$ and $1.04 \mathrm{mg} / 1$ with a mean concentration of $0.38 \mathrm{mg} / 1$ which was above the recommended regulatory (GHEPA) limit of $0.2 \mathrm{mg} / \mathrm{l}$.

Values of weak acid dissociation cyanide (CN-WAD) recorded during the sampling period ranged between $<0.005$ and $1.04 \mathrm{mg} / \mathrm{l}$ with a mean of $0.342 \mathrm{mg} / \mathrm{l}$ and was well below the GHEPA effluent discharge limit of $0.6 \mathrm{mg} / \mathrm{l}$.

Arsenic concentration in TSF-DW ranged from 0.17 to $5 \mathrm{mg} / \mathrm{l}$. Mean arsenic concentration of $1.26 \mathrm{mg} / \mathrm{l}$ far exceeded the GHEPA guideline limit of $0.1 \mathrm{mg} / \mathrm{l}$ in TSF-DW. Arsenic concentration exceeded regulatory guideline limits in all months sampled.

Values of copper recorded ranged from 0.058 to $0.35 \mathrm{mg} / \mathrm{l}$ with a mean concentration of $0.15 \mathrm{mg} / \mathrm{l}$ which was far below the GHEPA guideline limit of $5 \mathrm{mg} / \mathrm{l}$ for effluent discharge.

Mercury concentrations recorded in TSF-DW ranged between $<0.0001$ and $0.0002 \mathrm{mg} / \mathrm{l}$ with a mean of $0.002 \mathrm{mg} / \mathrm{l}$ and was well within the GHEPA guideline limit of $0.006 \mathrm{mg} / \mathrm{l}$.

Concentration of cadmium in TSF-DW varied from 0.0001 to $0.0004 \mathrm{mg} / \mathrm{l}$. Mean cadmium concentration in TSF-DW was $0.0002 \mathrm{mg} / 1$ and was well within the GHEPA guideline limit of $0.1 \mathrm{mg} / 1$ for effluent discharge.

\subsection{Water Quality of Groundwater Monitoring Boreholes within $500 \mathrm{~m}$ Radius of the TSF}

Values recorded for $\mathrm{pH}$, electrical conductivity, total dissolved solids and total suspended solids in groundwater samples within $500 \mathrm{~m}$ radius of the TSF were consistent with baseline values of the project site and also well within their respective regulatory guidelines.

Similarly, arsenic and copper also recorded values within the WHO guideline limits for potable water and also consistent with the baseline data. Biochemical oxygen demand, true color, cadmium, arsenic and cyanide (free, total and WAD) recorded values that were below their respective laboratory detection limits. Table 2 presents further details of groundwater quality data of the study. 
Table 2. Physical and chemical parameters of groundwater monitoring boreholes within $500 \mathrm{~m}$ radius of the TSF

\begin{tabular}{|c|c|c|c|c|c|c|c|c|c|c|c|c|c|c|}
\hline \multicolumn{5}{|c|}{$\mathrm{pH}$} & \multicolumn{5}{|c|}{ Electrical conductivity $(\mu \mathrm{s} / \mathrm{cm})$} & \multicolumn{5}{|c|}{ Total Dissolved Solids (mg/l) } \\
\hline $\begin{array}{c}\text { Monitoring } \\
\text { bore }\end{array}$ & Mean & SD & Range & P-value & $\begin{array}{c}\text { Monitoring } \\
\text { bore }\end{array}$ & Mean & SD & Range & P-value & $\begin{array}{c}\text { Monitoring } \\
\text { bore }\end{array}$ & Mean & SD & Range & P-value \\
\hline TSFMBB02A & 6.13 & 0.18 & $5.8-6.3$ & & TSFMBB02A & 129.43 & 13.44 & $108-152$ & & TSFMB02A & 84.29 & 9.45 & $70-99$ & \\
\hline TSFMB02B & 6.34 & 0.16 & $6-6.5$ & & TSFMBO2B & 190.85 & 23.84 & $168-237$ & & TSFMB02B & 124 & 16.83 & $109-154$ & \\
\hline TSFMB03A & 7.05 & 0.22 & $6.7-7.3$ & & TSFMB03A & 441.85 & 89.74 & $277-557$ & & TSFMB03A & 285.86 & 61.44 & $180-357$ & \\
\hline TSFMB03B & 7.64 & 0.15 & $7.5-7.9$ & & TSFMB03B & 373.71 & 6.32 & $366-385$ & & TSFMB03B & 242.29 & 5.5 & $233-250$ & \\
\hline TSFMB04A & 6 & 0 & 6 & & TSFMB04A & 114.71 & 5.42 & $106-120$ & & TSFMB04A & 74.57 & 3.82 & $69-78$ & \\
\hline TSFMB04B & 6.03 & 0.05 & $6-6.1$ & 4.79E-26 & TSFMB04B & 128.14 & 24.08 & $110-173$ & $2.35 \mathrm{E}-35$ & TSFMB04B & 82.86 & 17.26 & $70-113$ & 4.83E-35 \\
\hline TSFMB05 & 7.16 & 0.17 & $6.9-7.3$ & & TSFMB05 & 362.71 & 75.59 & $179-405$ & & TSFMB05 & 252.71 & 9.89 & $236-263$ & \\
\hline TSFMB06 & 6.83 & 0.12 & $6.7-7$ & & TSFMBO6 & 190.85 & 13.07 & $179-210$ & & TSFMB06 & 124.29 & 9.14 & $116-137$ & \\
\hline TSFMB07 & 6.91 & 0.45 & $6.2-7.4$ & & TSFMB07 & 208.56 & 5.07 & $201-215$ & & TSFMB07 & 135.71 & 3.64 & $131-140$ & \\
\hline TSFMB08A & 6.44 & 0.4 & $6-7.1$ & & TSFMB08A & 134 & 3.16 & $129-139$ & & TSFMB08A & 87.14 & 2.12 & $84-90$ & \\
\hline TSFMB08B & 6.46 & 0.3 & $6.1-6.9$ & & TSFMB08B & 187 & 13.18 & $165-207$ & & TSFMB08B & 121.43 & 9.4 & $107-135$ & \\
\hline \multicolumn{5}{|c|}{ Total Suspended Solids (mg/l) } & \multicolumn{5}{|c|}{ Dissolved Arsenic (mg/l) } & \multicolumn{5}{|c|}{ Dissolved Copper (mg/l) } \\
\hline $\begin{array}{c}\text { Monitoring } \\
\text { bore }\end{array}$ & Mean & $\mathrm{SD}$ & Range & P-value & $\begin{array}{c}\text { Monitoring } \\
\text { bore }\end{array}$ & Mean & SD & Range & P-value & $\begin{array}{c}\text { Monitoring } \\
\text { bore }\end{array}$ & Mean & $\mathrm{SD}$ & Range & P-value \\
\hline TSFMBO2A & 10.57 & 19.04 & $<1-53$ & & TSFMB2A & 0.00057 & 0.00012 & $0.0005-0.0007$ & & TSFMB2A & 0.001 & $\mathrm{NA}$ & $<0.0001-0.001$ & \\
\hline TSFMBO2B & 8.29 & 4.57 & 14-Feb & & TSFMB2B & 0.0009 & 0.00014 & $0.0008-0.001$ & & TSFMB2B & 0.001 & 0 & $<0.0001-0.001$ & \\
\hline TSFMB03A & 5.43 & 3.69 & 12-Jan & & TSFMB3A & 0.00254 & 0.00401 & $0.0005-0.0097$ & & TSFMB3A & 0.002 & 0.001 & $0.001-0.003$ & \\
\hline TSFMBO3B & 4.43 & 1.9 & 7-Feb & & TSFMB3B & 0.00633 & 0.004 & $0.0021-0.013$ & & TSFMB3B & 0.00186 & 0.00069 & $0.001-0.003$ & \\
\hline TSFMBO4A & 8.43 & 7.21 & 19-Jan & & TSFMB4A & 0.0005 & NA & $0.0005-0.0005$ & & TSFMB4A & 0.00267 & 0.00116 & $0.002-0.004$ & \\
\hline TSFMBO4B & 23.86 & 37.75 & $<1-102$ & 0.0062 & TSFMBAB & 0.00055 & 7.07E-05 & $0.0005-0.0006$ & 0.107592 & TSFMB4B & 0.00165 & 0.00191 & $0.0003-0.003$ & 0.14669 \\
\hline TSFMBO5 & 29.57 & 16.59 & $<1-53$ & & TSFMBO5 & 0.0008 & 0.00042 & $<0.00010-0.0012$ & & TSFMBO5 & 0.0015 & 0.00071 & $0.001-0.002$ & \\
\hline TSFMBO6 & 7.57 & 7.98 & $<1-18$ & & TSFMBO6 & 0.00126 & 0.00067 & $0.0001-0.0018$ & & TSFMBO6 & 0.001 & 0 & 0.001 & \\
\hline TSFMBO7 & 4.71 & 5.56 & $<1-16$ & & TSFMBO7 & 0.0006 & 0 & $0.0006-0.0006$ & & TSFMBO7 & $<0.001$ & NA & $<0.0001$ & \\
\hline TSFMBO8A & 2.29 & 2.81 & $<1-8$ & & TSFMB8A & 0.00088 & 0.00056 & $0.0005-0.0017$ & & TSFMB8A & $<0.001$ & 0 & $<0.0001-0.002$ & \\
\hline TSFMB08B & 5 & 0.79 & $<1-2$ & & TSFMB $8 B$ & 0.00063 & 0.00015 & $0.0005-0.0008$ & & TSFMB8B & 0.001 & 0 & $<0.0001-0.001$ & \\
\hline
\end{tabular}

Note. TSFMB=Tailings Storage Facility Monitoring Borehole, NA=Not Applicable

\subsection{Physical and Chemical Parameters of Surface Water within $500 \mathrm{~m}$ radius of the TSF}

\subsubsection{Arsenic}

Arsenic concentration in surface water within $500 \mathrm{~m}$ radius of the TSF varied from 0.001 to $0.021 \mathrm{mg} / \mathrm{l}$. The highest mean concentration of arsenic recorded in surface water was above the WHO (2011) guideline limit for potable water in PWSD whereas the lowest was recorded in BAN-T and TSFNWS respectively. The difference $(\mathrm{P}>0.05)$ between the means of surface water studied were statistically insignificant. Figure 2 presents dissolved arsenic concentration in surface water compared with the baseline mean $(0.003 \mathrm{mg} / \mathrm{l})$ and WHO (2011) guideline for potable water. 


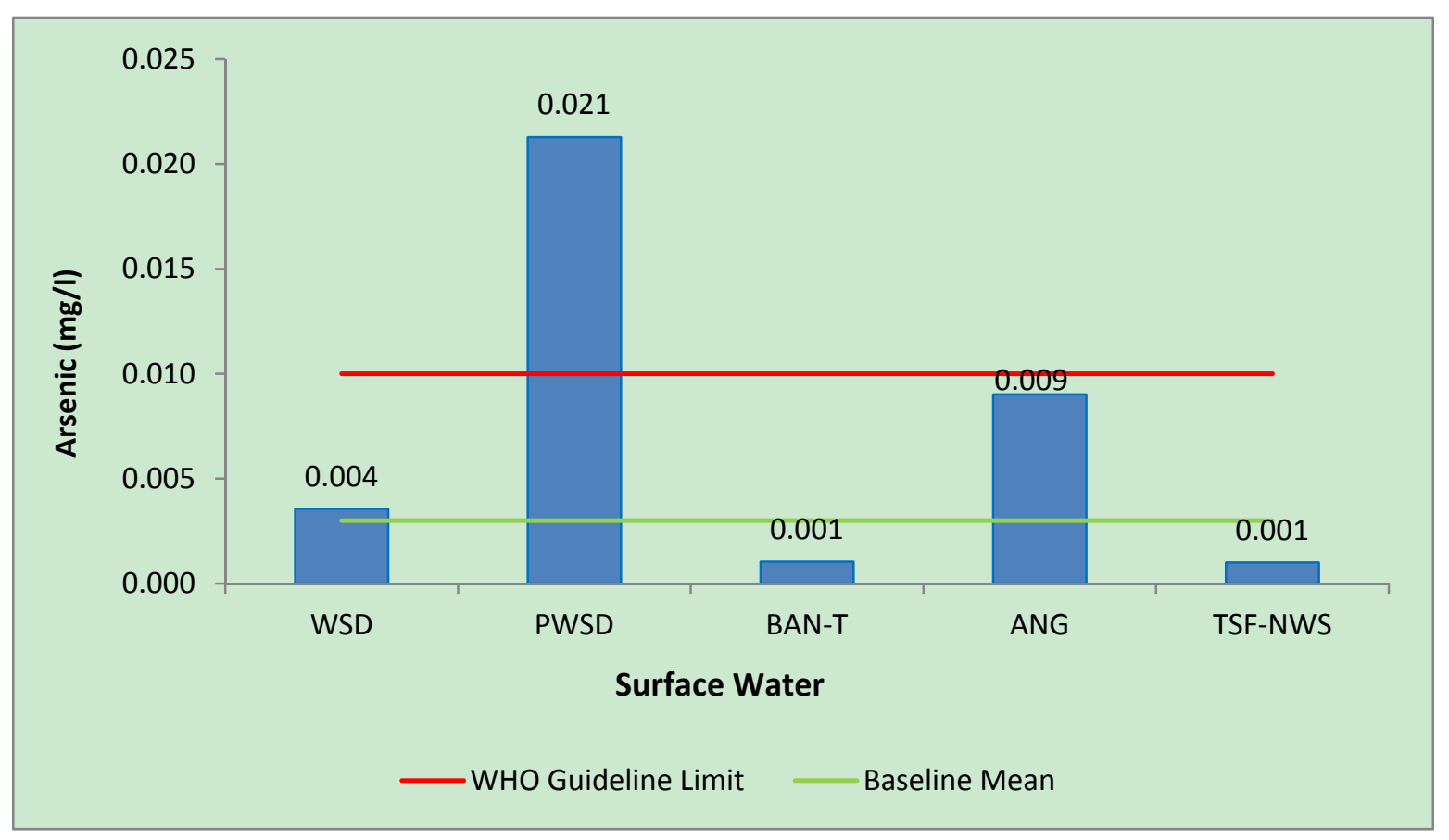

Figure 2. Arsenic Concentration of Surface Water within 500m radius of TSF compared with WHO (2011) Guideline and Baseline mean

\subsubsection{Copper}

The maximum concentration of copper $(0.0035 \mathrm{mg} / \mathrm{l})$ was recorded at PWSD while the minimum was $(0.001 \mathrm{mg} / \mathrm{l})$ recorded at BAN-T. Statistically, the difference $(\mathrm{P}>0.05)$ between the mean values of the various surface water sampling sites were insignificant. Mean copper concentration of $0.0020 \mathrm{mg} / \mathrm{l}$ was consistent with the baseline mean and also within the WHO guideline limit of $2 \mathrm{mg} / \mathrm{l}$ for surface water.

\subsubsection{Cyanide (Total, Free and WAD), Mercury and Cadmium}

Cyanide (Total, free and WAD), mercury and cadmium concentrations recorded in surface water around the TSF were all below their respective laboratory detection limits during the study.

\subsection{Pearson's Product Moment Correlation between Parameters}

\subsubsection{TSF Decant Water}

Pearson's product moment correlation matrix was carried out to determine the degree, strength or direction of the relationship between the parameters in TSF-DW. The results revealed that $\mathrm{pH}$ had moderate positive relationship with mercury, with a correlation coefficient ( $\mathrm{r}$ ) of 0.56 . Electrical conductivity had a highly significant positive correlation with dissolved arsenic, cadmium and copper (EC-As, $r=0.5), E C-C d, r=0.6), E C-C u, r=$ 0.72 ). EC also correlated moderately positive with free cyanide (EC- $\mathrm{CN}-\mathrm{f}, \mathrm{r}=0.58$ ). There was a strong positive correlation between TDS and cadmium as well as TDS and copper (TDS-Cd, $r=0.67$, TDS-Cu, $r=0.71$ ) respectively. However, a very weak negative correlation was reported between TDS and mercury (Hg) (TDS-Hg, $\mathrm{r}=-0.0122$ ). There was also a moderate positive correlation between TDS and free cyanide as well as TDS and arsenic (TDS- $\mathrm{CN}-\mathrm{f}, \mathrm{r}=0.56$, TDS-As, $\mathrm{r}=0.48$ ) respectively. True colour had a weak negative correlation with dissolved Arsenic, cadmium, WAD and free cyanide. Correlations between TSS and cadmium as well as dissolved mercury were weak and negative respectively. (TSS-Cadmium, $r=-0.29$, TSS-Hg, $r=-0.018$ ).

\subsubsection{Groundwater}

A very strong negative correlation between groundwater $\mathrm{pH}$ and copper $(\mathrm{pH}-\mathrm{Cu}, \mathrm{r}=-0.699)$ was recorded. No defined relationship could be established between groundwater $\mathrm{pH}$, mercury and cadmium because the concentrations of these metals in groundwater s a mples were below their respective detection limits. Pearson's product moment correlation revealed that $\mathrm{EC}$ had a weak positive correlation with copper $(\mathrm{EC}-\mathrm{Cu}, \mathrm{r}=0.29)$. The relationship between EC and arsenic was however weak and negative (EC-As, $r=-0.22$ ). TDS had a strong positive correlation with copper (TDS-Cu, $\mathrm{r}=0.65$ ). The correlation between TDS and arsenic was very weak and 
negative (TDS-As, $r=-0.097$ ). There was no defined relation between TDS and cyanide (Free, WAD, and Total). This is because cyanide was not detected in groundwater.

\subsubsection{Surface Water}

Pearson's product moment correlation revealed that surface water $\mathrm{pH}$ had a very weak negative correlation with copper ( $\mathrm{pH}-\mathrm{Cu}, \mathrm{r}=-0.16$ ). The relationship between $\mathrm{pH}$ and other metals studied as well as cyanide could not be established because the values recorded were below detection limits. The electrical conductivity of surface water recorded a weak positive correlation with copper $(\mathrm{EC}-\mathrm{Cu}, \mathrm{r}=0.27)$. The relationship between electrical conductivity of surface water and other metals as well as with cyanide could not be defined owing to the same reason above. There was a strong positive correlation between TDS and copper (TDS- $\mathrm{Cu}, \mathrm{r}=0.88$ ) as shown in Appendix D. Surface water true colour had a weak negative correlation with dissolved copper (Colour- Copper, $\mathrm{r}=$ $-0.34)$.

\section{Discussion and Conclusion}

\subsection{Physical Parameters}

The mean $\mathrm{pH}$ of 8.2 reported in ARL's TSF Decant Water (TSF-DW) was in agreement with a report by Acheampong et al. (2013) on TSF-DW at Bibiani mine. The slightly alkaline pH of the TSF water could be attributed to addition of lime during the beneficiation process at the mine. The mean $\mathrm{pH}$ of ground and surface water (6.67 and 6.63 respectively) within the catchment of the TSF were near neutral and within the WHO guideline limit for potable water. This suggests that $\mathrm{pH}$ of the TSF-DW has not adversely affected the surrounding water bodies and their life forms. Additionally, the slightly alkaline $\mathrm{pH}$ of the TSF-DW describes ARL's tailings as non-acid generating and therefore presents less risk of catchment water bodies being polluted as a result Acid Mine Drainage (ARD).

According to Shinoda, Nakagawa \& Tamamushi, (2013), electrical conductivity of water depends on the quantity of dissolved salts present and for dilute solutions, it is approximately proportional to the total dissolved solid (TDS) content. The presence of dissolved salts in water increases its electrical conductivity and varies based on temperature. High electrical conductivity in the TSF-DW $(1147.6 \mu \mathrm{S} / \mathrm{cm})$ with relatively low mean EC of 116.8 $\mu \mathrm{S} / \mathrm{cm}$ and $223.8 \mu \mathrm{S} / \mathrm{cm}$ recorded for surface and groundwater respectively suggests that TSF-DW does not have any perceptible impact on surrounding water bodies as far as EC is concerned. The high content of EC in TSF-DW could be attributed to free ions originating from reagents such as $\mathrm{HCl}$ which were used in the ore treatment process.

The high TDS of $964.6 \mathrm{mg} / \mathrm{l}$ in the TSF-DW was above the WHO limit of $500 \mathrm{mg} / \mathrm{l}$ for potable water. Low and acceptable amount of TDS in surrounding ground and surface water suggest no detrimental impacts. Biochemical oxygen demand is an estimate of the quantity of oxygen used by microorganisms such as aerobic bacteria in the oxidation of organic matter (Preininger, Klimant, \& Wolfbeis, 1994). Mean Biochemical Oxygen Demand (BOD) in all media studied were below detection limit. This observation suggests that organic contamination was non-existent in the media studied. Results from the study suggest that true colour of TSF-DW and water bodies within its catchment are independent of each other.

There is no WHO guideline available for TSS. Spikes in TSS recorded in June and July for TSF-DW could be attributed to washouts from bare embankment of the TSF during the rainy season as observed during the sampling regime. Slurry discharge into the TSF could also contribute to the high TSS in TSF-DW. The PWSD sampling sites is located uphill of the TSF and a receptor to effluents from illegal mining sites on ARL's concession. High TSS in PWSD could possibly be as a result of effluent discharge from the illegal mining sites located uphill. Water bodies with high TSS could harbor pathogens that may be harmful to humans and therefore not suitable for drinking (Noble, Lee, \& Schiff, 2004). High TSS could also reduce the rate of photosynthesis in aquatic environment.

\subsection{Chemical Parameters}

\subsubsection{Cyanide}

Cyanide is a toxic substance that renders tissues incapable of oxygen exchange (Shifrin, Beck, Gauthier, Chapnick, \& Goodman, 1996). Elevated concentrations of cyanide in water is hazardous to man and wildlife, particularly migrating bats and waterfowls (Eisler, Clark, Wiemeyer \& Henny, 1999). Cyanide contamination of the TSF-DW could be attributed to its use as a process chemical by Adamus Resources Limited as recounted by Acheampong et al. (2013) at Bogoso mine. High free cyanide concentration relative to other cyanide species (Total, and WAD) could possibly be attributed to excessive use of cyanide at the process plant relative to the rate at which they are broken down by natural processes. 
Significant concentration of cyanide in the TSF with non-detection in water bodies around the facility suggests that cyanide in the TSF-DW has not impacted on catchment water resources. This could possibly be attributed to adherence to the industry's best practices as observed at ARL during this study.

\subsubsection{Arsenic, Cadmium, and Mercury}

Arsenic (As) is an identified carcinogen, mutagen, and teratogen and it is associated with increasing risk of bladder, kidney, liver and lung tumors (Kortatsi et al., 2008). Chronic and acute poisoning by arsenic due to exposure to elevated concentrations is a common occurrence. High arsenic concentration in TSF-DW could be attributed to leaching of the element by cyanide from arsenopyrite ore mined by ARL (Armah et al., 2010). Welch, Lico, \& Hughes (1988) reported that arsenic is an important auxiliary contaminant in mine waters, particularly where the ore bodies contain arsenopyrite as is the case at ARL.

Low arsenic concentration in groundwater although TSF-DW recorded high concentrations could be attributed to arsenic's ability to bind strongly to soil and therefore does not travel downward toward aquifers very quickly (Woo \& Choi, 2001). Low arsenic in groundwater could also be attributed to effective liner application systems of ARL's TSF as suggested by Vick (1990). Findings from the study suggest that TSF has no impact on surrounding water bodies with respect to arsenic contamination. The spike in arsenic concentration seen in PWSD is an isolated case and may be due to influx of effluents from uphill-illegal mining activities during the rainy season.

Cadmium and Mercury are important factors in aquatic monitoring studies. This is because they have been found to be toxic to fish and other aquatic organisms (Essumang, Dodoo, Obiri, \& Yaney, 2007). Even though significant concentration of dissolved mercury and cadmium (below GHEPA limit for effluent discharge) was reported in the TSF-DW, the concentrations of these metals in surface and groundwater within $500 \mathrm{~m}$ radius of the TSF were all below their respective laboratory detection limits. The results suggest that concentration of mercury and cadmium in the TSF-DW has not affected the quality of water within the vicinity of the facility.

High levels of copper are associated with nausea, abdominal pain, or vomiting in humans (Pizarro et al., 1999). Concentrations of copper in groundwater $(0.0015 \mathrm{mg} / \mathrm{l})$ were greater than that of surface water $(0.0020 \mathrm{mg} / \mathrm{l})$. This notwithstanding, TSF-DW has no impact on catchment water bodies with respect to copper contamination as per the results obtained from the study.

\subsection{Relationships between Parameters}

Free ions of $\mathrm{Cd}, \mathrm{Cu}, \mathrm{CN}-\mathrm{f}$ and As could account for the high EC recorded in TSF- DW and these ions could be originating from a single source (the ore) as per the results of the correlation analysis.

The strong positive correlation between arsenic in TSF-DW with cyanide total, free and WAD (As/CN-T, $r=$ 0.855 , As/CN-F, $r=0.85$, As/CN-WAD, $r=0.934$ ) suggests that arsenic in the TSF-DW is leached from arsenopyrite ore by cyanide.

\section{Conclusion}

Concentration of key Ghana Environmental Protection Agency (GHEPA) conventional pollutants in ARL'S TSF decant water was above the agency's guideline limit for the mining sector. This indicates that the TSF-DW of ARL is contaminated. However, the concentration of Ghana Environmental Protection Agency (GHEPA) conventional pollutants in surface water and groundwater monitoring boreholes within $500 \mathrm{~m}$ radius of the tailings dam were generally within acceptable GHEPA, Ghana Water Company, and World Health Organization (WHO) guidelines.

Concentration of pollutants recorded for surface and groundwater monitoring boreholes were also consistent with baseline data from the mine. The TSF of ARL therefore has no perceptible impact on the quality of surface and groundwater within its vicinity.

\section{Acknowledgement}

The authors wish to express their profound gratitude to University of Ghana-Carnegie (New York) Next Generation of Academics in Africa Project for funding this work. The authors are also grateful to Mr. George Owusu Ansah, the Environmental Manager of Adamus Resources Limited (Nzema Gold Mine), for his support.

\section{References}

Acheampong, M. A., Adiyiah, J., \& Ansa, E. D. O. (2013). Physico-chemical characteristics of a gold mining tailings dam wastewater. Journal of Environmental Science and Engineering, 2, 469-475.

Ahmad, K., \& Carboo, D. (2000). Speciation of As (III) and As (V) in some Ghanaian gold tailings by a simple distillation method. Water, Air, and Soil Pollution, 122(3-4), 317-326. http://dx.doi.org/10.1023/A:1005286832435 
Akabzaa, T. M., Banoeng-Yakubu, B., \& Seyire, J. S. (2005). Heavy metal contamination in some mining communities within Jimi river basin in Ashanti Region. Journal of the Ghana Science Association, 7(1), $36-45$.

Armah, F. A., Obiri, S., Yawson, D. O., Onumah, E. E., Yengoh, G. T., Afrifa, E. K., \& Odoi, J. O. (2010). Anthropogenic sources and environmentally relevant concentrations of heavy metals in surface water of a mining district in Ghana: a multivariate statistical approach. Journal of Environmental Science and Health Part A, 45(13), 1804-1813. http://dx.doi.org/10.1080/10934529.2010.513296

Azcue, J. M., Mudroch, A., Rosa, F., \& Hall, G. E. M. (1994). Effects of abandoned gold mine tailings on the arsenic concentrations in water and sediments of Jack of Clubs Lake, BC. Environmental Technology, 15(7), 669-678. http://dx.doi.org/10.1080/09593339409385472

Davies, M. P. (2002). Tailings impoundment failures: are geotechnical engineers listening. Geotechnical News, September, 2002, 31-36.

Dzigbodi-Adjimah, K. (1993). Geology and geochemical patterns of the Birimian gold deposits, Ghana, West $\begin{array}{llll}\text { Africa. Journal of Geochemical } & \text { Exploration, }\end{array}$ http://dx.doi.org/10.1016/0375-6742(93)90073-U

Eisler, R., Clark Jr, D. R., Wiemeyer, S. N., \& Henny, C. J. (1999). Sodium cyanide hazards to fish and other wildlife from gold mining operations. In Environmental Impacts of Mining Activities (pp. 55-67). Berlin Heidelberg: Springer. http://dx.doi.org/10.1007/978-3-642-59891-3_5

Essumang, D. K., Dodoo, D. K., Obiri, S., \& Yaney, J. Y. (2007). Arsenic, cadmium, and mercury in cocoyam (Xanthosoma sagititolium) and watercocoyam (Colocasia esculenta) in Tarkwa a mining community. Bulletin $\begin{array}{llll}\text { of Environmental Contamination and Toxicology, } & \text { 79(4), 377-379. }\end{array}$ http://dx.doi.org/10.1007/s00128-007-9244-1

Hilson, G. M. (2005). Structural adjustment in Ghana: Assessing the impacts of mining-sector reform. Africa Today, 51(2), 53-77. http://dx.doi.org/10.1353/at.2005.0006

Hinton, J., Veiga, M. M., \& Beinhoff, C. (2003). Women and artisanal mining: Gender roles and the road ahead. The Socio-Economic Impacts of Artisanal and Small-Scale Mining in Developing Countries. AA Balkema, Sweets Publishers, Netherlands. http://dx.doi.org/10.1201/9780203971284.ch11

Ichino, N., \& Nathan, N. L. (2013). Crossing the line: Local ethnic geography and voting in Ghana. American Political Science Review, 107(02), 344-361. http://dx.doi.org/10.1017/S0003055412000664

Knight Piesold. (2007). Environmental Impact Asssessment of Adamus Resources Limited. Airport, Accra: Knight Piesold.

Kortatsi, B. K., Asigbe, J., Dartey, G. A., Tay, C., Anornu, G. K., \& Hayford, E. (2008). Reconnaissance Survey of arsenic concentration in ground-water in South-eastern Ghana. West African Journal of Applied Ecology, 13(1), 16-26. http://dx.doi.org/10.4314/wajae.v13i1.40586

Kuhn, D. D., \& Young, T. C. (2005). Photolytic degradation of hexacyanoferrate (II) in aqueous media: The determination of the degradation kinetics. Chemosphere, 60(9), 1222-1230. http://dx.doi.org/10.1016/j.chemosphere.2005.02.011

Leube, A., Hirdes, W., Mauer, R., \& Kesse, G. O. (1990). The early Proterozoic Birimian Supergroup of Ghana and some aspects of its associated gold mineralization. Precambrian Research, 46(1-2), 139-165. http://dx.doi.org/10.1016/0301-9268(90)90070-7

Liu, Y. G., Zhou, M., Zeng, G. M., Wang, X., Li, X., Fan, T., \& Xu, W. H. (2008). Bioleaching of heavy metals from mine tailings by indigenous sulfur-oxidizing bacteria: effects of substrate concentration. Bioresource Technology, 99(10), 4124-4129. http://dx.doi.org/10.1016/j.biortech.2007.08.064

Noble, R. T., Lee, I. M., \& Schiff, K. C. (2004). Inactivation of indicator micro-organisms from various sources of faecal contamination in seawater and freshwater. Journal of Applied Microbiology, 96(3), 464-472. http://dx.doi.org/10.1111/j.1365-2672.2004.02155.x

Parizek, R. R., \& Lane, B. E. (1970). Soil-water sampling using pan and deep pressure-vacuum lysimeters. Journal of Hydrology, 11(1), 1-21. http://dx.doi.org/10.1016/0022-1694(70)90111-3

Paull, D., Banks, G., Ballard, C., \& Gillieson, D. (2006). Monitoring the environmental impact of mining in remote locations through remotely sensed data. Geocarto International, 21(1), 33-42. http://dx.doi.org/10.1080/10106040608542372 
Pizarro, F., Olivares, M., Uauy, R., Contreras, P., Rebelo, A., \& Gidi, V. (1999). Acute gastrointestinal effects of graded levels of copper in drinking water. Environmental Health Perspectives, 107(2), 117. http://dx.doi.org/10.1289/ehp.99107117

Preininger, C., Klimant, I., \& Wolfbeis, O. S. (1994). Optical fiber sensor for biological oxygen demand. Analytical Chemistry, 66(11), 1841-1846. http://dx.doi.org/10.1021/ac00083a011

Rico, M., Benito, G., Salgueiro, A. R., Díez-Herrero, A., \& Pereira, H. G. (2008). Reported tailings dam failures: a review of the European incidents in the worldwide context. Journal of Hazardous Materials, 152(2), 846-852. http://dx.doi.org/10.1016/j.jhazmat.2007.07.050

Roussel, C., Néel, C., \& Bril, H. (2000). Minerals controlling arsenic and lead solubility in an abandoned gold mine tailing. Science of the Total Environment, 263(1), 209-219. http://dx.doi.org/10.1016/S0048-9697(00)00707-5

Serfor-Armah, Y., Nyarko, B. J. B., Dampare, S. B., \& Adomako, D. (2006). Levels of arsenic and antimony in water and sediment from Prestea, a gold mining town in Ghana and its environs. Water, Air, and Soil Pollution, 175(1-4), 181-192. http://dx.doi.org/10.1007/s11270-006-9127-9

Shifrin, N. S., Beck, B. D., Gauthier, T. D., Chapnick, S. D., \& Goodman, G. (1996). Chemistry, toxicology, and human health risk of cyanide compounds in soils at former manufactured gas plant sites. Regulatory Toxicology and Pharmacology, 23(2), 106-116. http://dx.doi.org/10.1006/rtph.1996.0032

Shinoda, K., Nakagawa, T., \& Tamamushi, B. I. (2013). Colloidal surfactants: some physicochemical properties (Vol. 12). Elsevier.

Singh, K. P., Malik, A., Mohan, D., \& Sinha, S. (2004). Multivariate statistical techniques for the evaluation of spatial and temporal variations in water quality of Gomti River (India) - a case study. Water Research, 38(18), 3980-3992. http://dx.doi.org/10.1016/j.watres.2004.06.011

Smedley, P. L., Edmunds, W. M., \& Pelig-Ba, K. B. (1996). Mobility of arsenic in groundwater in the Obuasi gold-mining area of Ghana: some implications for human health. Geological Society, London, Special Publications, 113(1), 163-181. http://dx.doi.org/10.1144/GSL.SP.1996.113.01.13

Vick, S. G. (1990). Planning, design, and analysis of tailings dams. Vancouver: BiTech.

Welch, A. H., Lico, M. S., \& Hughes, J. L. (1988). Arsenic in ground water of the western United States. Ground water, 26(3), 333-347. http://dx.doi.org/10.1111/j.1745-6584.1988.tb00397.x

Woo, N. C., \& Choi, M. J. (2001). Arsenic and metal contamination of water resources from mining wastes in Korea. Environmental Geology, 40(3), 305-311. http://dx.doi.org/10.1007/s002540000161

\section{Appendices}

Appendix A: Baseline Mean of Surface and Groundwater

\begin{tabular}{|c|c|c|c|}
\hline \multicolumn{2}{|c|}{ BASELINE MEAN } & & \\
\hline $\begin{array}{l}\text { TDS } \\
(\mathrm{mg} / \mathrm{l})\end{array}$ & $\begin{array}{l}\text { 3OD } \\
\mathrm{ng} / \mathrm{l})\end{array}$ & $\begin{array}{l}\mathrm{CN}-\mathrm{f} \\
\mathrm{ng} / \mathrm{l})\end{array}$ & $\begin{array}{c}\mathrm{Hg} \\
(\mathrm{mg} / \mathrm{l})\end{array}$ \\
\hline 218.6 & $<5$ & 0.01 & $<0.01$ \\
\hline 36.6 & $<5$ & 0.01 & $<0.01$ \\
\hline
\end{tabular}

Note. GW = Groundwater, $\mathrm{SW}=$ Surface water 
Appendix B: Pearson's Product Moment Correlation between Parameters Analyzed in the TSF

\begin{tabular}{|c|c|c|c|c|c|c|c|c|c|c|c|c|}
\hline & $\begin{array}{l}\text { Color } \\
\text { (TCU) }\end{array}$ & $\begin{array}{c}\mathrm{EC} \\
(\mu \mathrm{S} / \mathrm{cm}) \\
\end{array}$ & $\mathrm{pH}$ & $\begin{array}{r}\text { TDS } \\
(\mathrm{mg} / \mathrm{l}) \\
\end{array}$ & $\begin{array}{c}\text { TSS } \\
(\mathrm{mg} / \mathrm{l}) \\
\end{array}$ & $\begin{array}{l}\text { As-D } \\
(\mathrm{mg} / \mathrm{l}) \\
\end{array}$ & $\begin{array}{l}\text { Cd-D } \\
(\mathrm{mg} / \mathrm{l}) \\
\end{array}$ & $\begin{array}{l}\mathrm{Cu}-\mathrm{D} \\
(\mathrm{mg} / \mathrm{l}) \\
\end{array}$ & $\begin{array}{l}\mathrm{CN}-\mathrm{t} \\
(\mathrm{mg} / \mathrm{l}) \\
\end{array}$ & $\begin{array}{l}\mathrm{CN}-\mathrm{f} \\
(\mathrm{mg} / \mathrm{l}) \\
\end{array}$ & $\begin{array}{c}\text { CN-WAD } \\
(\mathrm{mg} / \mathrm{l})\end{array}$ & \begin{tabular}{|l|}
$\mathrm{Hg}-\mathrm{D}$ \\
$(\mathrm{mg} / \mathrm{l})$ \\
\end{tabular} \\
\hline Color (TCU) & 1 & & & & & & & & & & & \\
\hline $\mathrm{EC}(\mu \mathrm{S} / \mathrm{cm})$ & 0.29495634 & 1 & & & & & & & & & & \\
\hline $\mathrm{pH}$ & 0.420989673 & 0.580416816 & 1 & & & & & & & & & \\
\hline TDS (mg/l) & 0.31901237 & 0.999596535 & 0.593463126 & 1 & & & & & & & & \\
\hline TSS (mg/l) & -0.466428821 & -0.282076979 & -0.058371166 & -0.29638023 & 1 & & & & & & & \\
\hline As-D (mg/l) & -0.105150416 & 0.499112053 & 0.021833318 & 0.485835995 & 0.48411389 & 1 & & & & & & \\
\hline Cd-D (mg/l) & -0.058404965 & 0.67446824 & 0.371305329 & 0.669252883 & -0.297720225 & 0.046364152 & 1 & & & & & \\
\hline $\mathrm{Cu}-\mathrm{D}$ (mg/l) & 0.02820054 & 0.724199838 & 0.245545632 & 0.713875518 & 0.302884413 & 0.869753834 & 0.486569586 & 1 & & & & \\
\hline CN-t (mg/l) & 0.173896045 & 0.447964118 & -0.101124583 & 0.443277962 & 0.110366707 & 0.855803744 & -0.187608735 & 0.632472645 & 1 & & & \\
\hline $\mathrm{CN}-\mathrm{f}(\mathrm{mg} / \mathrm{l})$ & -0.236985306 & 0.585111147 & 0.094179997 & 0.56825964 & 0.449166411 & 0.850357061 & 0.492871173 & 0.958593748 & 0.52304438 & 1 & & \\
\hline CN-WAD (mg/l) & -0.18895113 & 0.285836964 & -0.319601342 & 0.269440039 & 0.460039481 & 0.934780109 & -0.107784126 & 0.729405878 & 0.85771618 & 0.7523006 & 1 & \\
\hline Hg-D (mg/l) & 0.393240824 & -0.141421356 & 0.5625 & -0.122709136 & -0.018507931 & -0.301021062 & -0.495073771 & -0.454299411 & -0.1407465 & -0.5871781 & -0.459235264 & 1 \\
\hline
\end{tabular}

Note. $\mathrm{RED}=$ Significant Correlation, $\mathrm{NR}=$ No Established Relationship

Appendix C: Pearson's Product Moment Correlation between Parameters Analyzed in Groundwater around the TSF

\begin{tabular}{|c|c|c|c|c|c|c|c|c|c|c|c|c|}
\hline & $\begin{array}{l}\text { Color } \\
\text { (TCU) }\end{array}$ & $\begin{array}{c}\mathrm{EC} \\
(\mu \mathrm{S} / \mathrm{cm}) \\
\end{array}$ & $\mathrm{pH}$ & $\begin{array}{r}\text { TDS } \\
(\mathrm{mg} / \mathrm{l})\end{array}$ & $\begin{array}{r}\text { TSS } \\
(\mathrm{mg} / \mathrm{l})\end{array}$ & $\begin{array}{l}\text { As-D } \\
(\mathrm{mg} / \mathrm{l})\end{array}$ & $\begin{array}{l}\text { Cd-D } \\
(\mathrm{mg} / \mathrm{l})\end{array}$ & $\begin{array}{l}\mathrm{Cu}-\mathrm{D} \\
(\mathrm{mg} / \mathrm{f})\end{array}$ & $\begin{array}{l}\text { CN-t } \\
(\mathrm{mg} / \mathrm{f})\end{array}$ & $\begin{array}{l}\mathrm{CN}-\mathrm{f} \\
(\mathrm{mg} / \mathrm{l})\end{array}$ & $\begin{array}{c}\text { CN-WAD } \\
(\mathrm{mg} / \mathrm{l})\end{array}$ & $\begin{array}{l}\mathrm{Hg}-\mathrm{D} \\
(\mathrm{mg} / \mathrm{l}) \\
\end{array}$ \\
\hline Color (TCU) & 1 & & & & & & & & & & & \\
\hline $\mathrm{EC}(\mu \mathrm{S} / \mathrm{cm})$ & NR & 1 & & & & & & & & & & \\
\hline $\mathrm{pH}$ & NR & -0.326835407 & 1 & & & & & & & & & \\
\hline $\mathrm{TDS}(\mathrm{mg} / \mathrm{l})$ & NR & 0.800411761 & -0.67712895 & 1 & & & & & & & & \\
\hline TSS (mg/l) & NR & -0.35984769 & -0.406743894 & 0.245079415 & 1 & & & & & & & \\
\hline As-D (mg/l) & NR & -0.218870108 & -0.187184192 & -0.097366941 & 0.274535635 & 1 & & & & & & \\
\hline Cd-D (mg/l) & NR & 0.264924337 & -0.723711055 & 0.777705685 & 0.790527901 & 0.082312 & 1 & & & & & \\
\hline $\mathrm{Cu}-\mathrm{D}(\mathrm{mg} / \mathrm{l})$ & NR & 0.294796757 & -0.699117613 & 0.645719031 & 0.46544283 & 0.505545 & 0.681782999 & 1 & & & & \\
\hline CN-t (mg/l) & NR & NR & NR & NR & NR & NR & NR & NR & 1 & & & \\
\hline CN-f(mg/l) & NR & NR & NR & NR & NR & NR & NR & NR & NR & 1 & & \\
\hline CN-WAD & & & & & & & & & & & & \\
\hline$(m g / l)$ & NR & NR & NR & NR & NR & NR & NR & NR & NR & NR & 1 & \\
\hline $\operatorname{Hg}-\mathrm{D}(\mathrm{mg} / \mathrm{l})$ & $\mathrm{NR}$ & $\mathrm{NR}$ & NR & NR & NR & NR & $\mathrm{NR}$ & NR & NR & NR & NR & 1 \\
\hline
\end{tabular}

Note. $\mathrm{RED}=$ Significant Correlation, NR=No Established Relationship 
Appendix D: Pearson's Product Moment Correlation between Parameters Analyzed in Surface water around the TSF

\begin{tabular}{|c|c|c|c|c|c|c|c|c|c|c|c|c|}
\hline & $\begin{array}{l}\text { Color } \\
(\mathrm{TCU}) \\
\end{array}$ & $\begin{array}{c}\mathrm{EC} \\
(\mu \mathrm{S} / \mathrm{cm})\end{array}$ & $\mathrm{pH}$ & $\begin{array}{c}\text { TDS } \\
(\mathrm{mg} / \mathrm{l})\end{array}$ & $\begin{array}{c}\text { TSS } \\
(\mathrm{mgl})\end{array}$ & $\begin{array}{l}\text { As-D } \\
(\mathrm{mg} / \mathrm{l})\end{array}$ & $\begin{array}{l}\mathrm{Cd}-\mathrm{D} \\
(\mathrm{mg} / \mathrm{l})\end{array}$ & $\begin{array}{l}\mathrm{Cu}-\mathrm{D} \\
(\mathrm{mg} / \mathrm{l})\end{array}$ & $\begin{array}{l}\mathrm{CN}-\mathrm{t} \\
(\mathrm{mg} / \mathrm{l})\end{array}$ & $\begin{array}{l}\mathrm{CN}-\mathrm{f} \\
(\mathrm{mg} / \mathrm{l})\end{array}$ & $\begin{array}{c}\text { CN-WAD } \\
(\mathrm{mg} /)\end{array}$ & $\begin{array}{l}\mathrm{Hg}-\mathrm{D} \\
(\mathrm{mg} / \mathrm{d})\end{array}$ \\
\hline Color (TCU) & 1 & & & & & & & & & & & \\
\hline $\mathrm{EC}(\mu \mathrm{S} / \mathrm{cm})$ & 0.220481 & 1 & & & & & & & & & & \\
\hline $\mathrm{pH}$ & 0.130198 & -0.315455099 & 1 & & & & & & & & & \\
\hline $\operatorname{TDS}(\mathrm{mg} / \mathrm{l})$ & -0.30634 & 0.007393158 & -0.145030092 & 1 & & & & & & & & \\
\hline TSS (mgll) & -0.36722 & 0.358360729 & 0.014011621 & 0.849372 & 1 & & & & & & & \\
\hline As-D (mgll) & -0.6539 & -0.443416829 & -0.430898348 & 0.466533 & 0.15703 & 1 & & & & & & \\
\hline Cd-D (mg/l) & NR & NR & NR & NR & NR & NR & 1 & & & & & \\
\hline Cu-D (mg/l) & -0.34469 & 0.278650617 & -0.169704958 & 0.881353 & 0.846698 & 0.361274808 & NR & 1 & & & & \\
\hline CN-t $(\mathrm{mg} / \mathrm{l})$ & NR & NR & NR & NR & NR & NR & NR & NR & 1 & & & \\
\hline $\mathrm{CN}-\mathrm{f}(\mathrm{mg} / \mathrm{l})$ & NR & NR & NR & NR & NR & NR & NR & NR & NR & 1 & & \\
\hline CN-WAD (mgl) & NR & NR & NR & NR & NR & NR & NR & NR & NR & NR & 1 & \\
\hline $\mathrm{Hg}-\mathrm{D}(\mathrm{mg} / \mathrm{l})$ & $\mathrm{NR}$ & NR & NR & NR & NR & NR & NR & $\mathrm{NR}$ & $\mathrm{NR}$ & $\mathrm{NR}$ & NR & 1 \\
\hline
\end{tabular}

Note. $\mathrm{RED}=$ Significant Correlation, $\mathrm{NR}=$ No Established Relationship

\section{Copyrights}

Copyright for this article is retained by the author(s), with first publication rights granted to the journal.

This is an open-access article distributed under the terms and conditions of the Creative Commons Attribution license (http://creativecommons.org/licenses/by/4.0/). 